\title{
Evaluasi Produk dan Pelayanan di Mc Donald's Menggunakan Service Quality
}

\author{
Erika Rahmawati, Dewi Andri Yaningsih, \\ Yovanka Rimamillennia
}

\author{
Program Studi Manajemen, Universitas Pembangunan Jaya
}

\begin{abstract}
Abstrak
Mc Donald's merupakan salah satu restoran fast food yang sangat diminati konsumen di berbagai daerah. Restoran ini menyajikan berbagai macam makanan siap saji yang menawarkan berbagai aspek - aspek lainnya seperti pelayanan jasa, harga, dan lain sebagainya. Hal ini diharapkan dapat memuaskan bagi para konsumen. Tujuan diadakan penelitian ini adalah untuk mengetahui karakteristik konsumen yang sering atau pernah menggunakan pelayanan di Mc Donald's, mengetahui kepuasan konsumen terhadap produk yang diberikan oleh restoran Mc Donald's ini, dan memperoleh hasil ekspetasi dari pelanggan terhadap layanan yang ditawarkan oleh restoran Mc Donald's. Survey ini digunakan untuk mengevaluasi harapan pelanggan terhadap layanan yang ditawarkan oleh restoran Mc Donald's yang terdiri dari pengukuran kinerja harapan terhadap kualitas layanan. Metodelogy yang kami gunakan adalah Accidental Sampling yang dimana pengambilan sampelnya dengan membagikan kuisioner kepada konsumen yang dijumpai atau secara kebetulan sedang membeli. Dengan adanya penelitian ini diharapkan dapat memberikan manfaat yaitu dengan diketahuinya karakteristik konsumen dan kepuasan konsumen dapat menjadi masukan yang bermanfaat bagi Mc Donald's agar mampu memperbaiki kualitas pelayanan yang kurang terhadap konsumen, dan mampu menghadapi persaingan antar restoran cepat saji yang lainnya.
\end{abstract}

Kata Kunci : kepuasan pelanggan, pelayanan jasa, konsumen, kualitas layanan, harapan pelanggan.

\section{PENDAHULUAN}

Pada era globalisasi ini perkembangan dunia usaha dan bisnis tumbuh pesat, menyisakan peluang dan juga tantangan. Hal ini diikuti dengan pola hidup manusia yang bergerak dengan cepat. Hal inilah menyebabkan manusia selalu menginginkan sesuatu barang, bahkan dalam hal makanan manusia ingin mendapatkannya dengan cepat atau instant. Sehingga tidak heran lagi apabila manusia pada jaman sekarang lebih menyukai makanan cepat saji (fast food). Mc Donald's memiliki visi menjadi salah satu restoran cepat saji dengan pelayanan terbaik di dunia, selalu menjamin mutu produk - produknya memberikan pelayanan yang memuaskan, menawarkan kebersihan dan keamanan produk pangan serta nilai - nilai tambah lainnya. Oleh karena itu, Mc Donald's harus bisa meningkatkan kualitas layanannya termasuk dalam hal produk maupun jasa agar dapat meningkatkan kepercayaan dan kepuasan pelanggan. Tim manajemen perlu menyadari bahwa perkembangan bisnis terus berubah dan tidak tetap sehingga perlu adanya upaya perbaikan yang berkesinambungan. Ukuran mengenai seberapa baik tingkat pelayanan yang diberikan mampu memenuhi ekspektasi pelanggan, pada umumnya disebut sebagai sebagai kualitas jasa. Upaya untuk memperbaiki kualitas jasa tidak hanya berdampak positif bagi pelanggan namun dapat juga meningkatkan kepuasan kerja bagi karyawan. Peran untuk mengubah organisasi tidak hanya datang dari tim manajemen namun juga harus datang dari karyawan. Dalam kualitas jasa, terdapat lima dimensi karateristik kualitas pelayanan yaitu tangibles, responsiveness, reability, assurance dan emphaty. Kelima dimensi inilah yang kemudian akan diuji menggunakan metode Service Quality atau bisa disingkat juga dengan istilah Servqual. 
Oleh karena itu, peneliti melakukan studi tentang "Evaluasi Produk dan Pelayanan di Mc Donald's Menggunakan Service Quality" berdasarkan lima dimensi jasa Servqual. Diharapkan dengan hasil penelitian nantinya dapat membuat Mc Donald's memaksimalkan kualitas pelayanannya. Berdasarkan latar belakang yang telah dikemukakan, maka rumusan masalah pada penelitian ini adalah mengidentifikasi atribut yang harus di evaluasi dan diperbaiki (tidak memenuhi harapan pelanggan), atribut yang perlu dipertahankan (berhasil memenuhi harapan pelanggan), atribut yang sudah memenuhi harapan pelanggan dan atribut yang perlu di evaluasi dan diperbaiki oleh Mc Donald's

\section{Kualitas Jasa}

\section{LANDASAN TEORI}

$>$ Jasa merupakan suatu bentuk kegiatan yang dilakukan oleh satu orang atau lebih, umumnya sifat jasa adalah tidak berbentuk dan tidak menghasilkan kepemilikan (Kotler \& Keller, 2016).

> Jasa merupakan semua aktivitas ekonomi yang hasillnya bukan berbentuk produk fisik atau konstruksi, yang umumnya dihasilkan dan dikonsumsi secara bersamaan serta memberikan nilai tambah seperti kenyamanan, hiburan, kesenangan, atau kesehatan bagi konsumen (Zeithaml \& Bitner, 1996).

$>$ Jasa merupakan setiap tindakan atau perbuatan yang dapat ditawarkan oleh suatu pihak kepada pihak lain dalam hal ini misalnya penjual dengan pembeli, dan pada dasarnya bersifat tidak berwujud fisik (intangible) dan tidak menghasilkan kepemilikan sesuatu sehingga jasa tersebut tidak dapat dilihat. (Tjiptono, 2000)

$>$ Kualitas jasa merupakan tanggapan konsumen terhadap jasa yang dikonsumsinya. Apabila kualitas jasa yang diterima oleh konsumen lebih baik atau sama dengan yang ia bayangkan, maka ia cenderung akan mencobanya kembali (Jasfar, 2005)

$>$ Kualitas jasa adalah sejauh mana jasa memenuhi spesifikasi - spesifikasinya. Salah satu pendekatan kualitas jasa adalah model SERQUALL (Servicee Quality). Singkat kata, kualitas jasa didefinisikan sebagai seberapa jauh perbedaan antara kenyataan dan harapan pelanggan atas layanan yang mereka terima (Lupiyoadi \& Hamdani, 2008)

$>$ Jasa adalah mencakup semua aktivitas ekonomi yang outputnya bukanlah produk atau kontruksi fisik, yang secara umum konsumsi dan produksinya dilakukan pada waktu yang sama, dan nilai tambah yang diberikan dalam bentuk (kenyamanan, liburan, kecepatan, dan kesehatan) yang secara prrinsip intangibles bagi pembeli pertamanya. (Yazid, 1999)

\section{Metode Service Quality (Servqual)}

$>$ Service Quality merupakan persepsi akan kualitas yang dimiliki oleh pelanggan, baik pelanggan eksternal maupun pelanggan internal (Tannady, Nurprihatin \& Hartono, 2018).

$>$ Service Quality merupakan sebuah kinerja yang dapat ditawarkan oleh seseorang kepada orang lain (Kotler, 2008)

> Service Quality merupakan evaluasi kognitif jangka panjang pelanggan terhadap penyerahan jasa suatu perusahaan. (Lovelock and Waright, 2007)

> Service Quality adalah suatu sikap dari hasil perbandingan pengharapan kualitas jasa konsumen dengan kinerja perusahaan yang dirasakan konsumen (Usmara, 2008).

> Service Quality adalah tingkat - tingkat ukuran atas kualitas pelayanan yang diasumsikan berhubungan dengan perkembangan harga (Roderick, James dan Gregory, 2008).

$>$ Service Quality adalah pemenuhan kebutuhan dan keinginan pelanggan serta ketepatan penyampaiannya untuk mengimbangi harapan pelanggan. Dengan demikian, ada dua faktor utama yang mempengaruhi kualitas jasa yaitu jasa yang diharapkan (expected service) dan jasa yang dirasakan/dipersepsikan (perceived service) (Tjiptono, 2002). 


\section{METODOLOGI PENELITIAN}

Jenis penelitian yang digunakan dalam penelitian ini adalah penelitian kuantitatif. Menurut Sugiyono (2012), metode penelitian kuantitatif dapat diartikan sebagai metode penelitian yang berlandaskan pada filsafat positivisme, digunakan untuk meneliti pada populasi atau sampel tertentu. Pengumpulan data dalam penelitian terdiri dari 2 langkah yaitu Persiapan, tahap ini dilakukan sebelum melakukan penelitian seperti mencari buku, jurnal dan landasan teori yang mendukung penelitian seperti teori kualitas jasa dan servqual. Melakukan studi pendahuluan dan studi literatur untuk lebih memahami topik yang diteliti dan merancang kuesioner. Isi kuisioner yang disusun mewakili 5 dimensi dalam kualitas jasa. Tahap kedua adalah Pengamatan, tahap ini memberikan kuesioner kepada responden, menggunakan metode simple random sampling. Jumlah responden dalam penelitian ini adalah 40 responden. Setelah melakukan penyebaran kuisoner dan mendapatkan data sebanyak 40 responden, maka langkah selanjutnya adalah melakukan pengolahan data dengan metode Servqual. Metode ini dimulai dengan menghitung gap/selisih antara harapan pelanggan mengenai layanan jasa dengan kenyataan pelayanan yang dirasakan pelanggan.

\section{Hasil Perhitungan Gap}

\section{ANALISIS DAN PEMBAHASAN}

Tabel 1 menunjukkan hasil perhitungan gap/selisih antara harapan dan persepsi pelanggan terhadap pelayanan jasa berdasarkan 12 atribut pernyataan kuisioner.

Tabel 1 Nilai Rata-Rata Gap 5 Terhadap Pernyataan Kualitas Layanan Jasa

\begin{tabular}{|c|c|c|c|c|c|}
\hline \multirow[b]{2}{*}{ Atribut } & \multicolumn{2}{|c|}{ Harapan Pelayanan } & \multicolumn{2}{|c|}{ Kenyataan Pelayanan } & \multirow[b]{2}{*}{$\begin{array}{c}\text { Nilai Gap } 5 \\
\text { Kolom ini } \\
\text { berisi Angka } \\
\text { pada Kolom } \\
\text { Rata-Rata } \\
\text { Nilai } \\
\text { Kenyataan - } \\
\text { Kolom } \\
\text { Rata-Rata } \\
\text { Nilai } \\
\text { Harapan } \\
\end{array}$} \\
\hline & $\begin{array}{l}\text { Bobot Nilai } \\
\text { Kolom ini } \\
\text { berisi } \\
\text { akumulasi } \\
\text { jumlah } \\
\text { bobot } \\
\text { jawaban } \\
\text { setiap } \\
\text { responden }\end{array}$ & $\begin{array}{l}\text { Rata-Rata Nilai Harapan } \\
\text { Kolom ini berisi Angka } \\
\text { pada kolom Bobot Nilai } \\
\text { dibagi Jumlah Responden }\end{array}$ & Bobot Nilai & $\begin{array}{l}\text { Rata-Rata Nilai } \\
\text { Kenyataan } \\
\text { Kolom ini berisi } \\
\text { Angka pada } \\
\text { kolom Bobot } \\
\text { Nilai dibagi } \\
\text { Jumlah } \\
\text { Responden }\end{array}$ & \\
\hline 1 & 160 & 4.0 & 154 & 3.85 & -0.15 \\
\hline 2 & 162 & 4.05 & 162 & 4.05 & 0 \\
\hline 3 & 168 & 4.20 & 166 & 4.15 & -0.05 \\
\hline 4 & 171 & 4.27 & 165 & 4.12 & -0.15 \\
\hline 5 & 164 & 4.10 & 152 & 3.80 & -0.3 \\
\hline 6 & 155 & 3.87 & 153 & 3.82 & -0.05 \\
\hline 7 & 158 & 3.95 & 154 & 3.85 & -0.1 \\
\hline 8 & 159 & 3.97 & 157 & 3.92 & -0.05 \\
\hline 9 & 159 & 3.97 & 159 & 3.97 & 0 \\
\hline 10 & 156 & 3.90 & 151 & 3.77 & -0.13 \\
\hline 11 & 162 & 4.05 & 172 & 4.30 & 0.25 \\
\hline 12 & 176 & 4.40 & 185 & 4.62 & 0.22 \\
\hline
\end{tabular}

\section{Perhitungan Dimensi Kualitas Jasa Berdasarkan Servqual Gap 5}


Lima dimensi dalam kualitas jasa menurut Zeithaml et al. (1985) terdiri dari reliability (keandalan), responsiveness (daya tanggap), assurance (jaminan), empathy (empati), dan tangibles (bukti fisik). Tabel 2 menunjukkan hasil perhitungan nilai rata-rata gap 5 berdasarkan lima dimensi servqual.

Tabel 2 Nilai rata-rata Gap 5 berdasarkan dimensi servqual Disesuaikan dengan isian Tabel 1 Anda

\begin{tabular}{ccccccc}
\hline Dimensi & Atribut & $\begin{array}{c}\text { Jumlah } \\
\text { Rata-Rata } \\
\text { Harapan }\end{array}$ & $\begin{array}{c}\text { Rata-Rata } \\
\text { Kenyataan }\end{array}$ & $\begin{array}{c}\text { Nilai } \\
\text { Harapan } \\
\text { Pelayanan }\end{array}$ & $\begin{array}{c}\text { Nilai } \\
\text { Kenyataan } \\
\text { Pelayanan }\end{array}$ & $\begin{array}{c}\text { Nilai Gap } \\
5\end{array}$ \\
\hline Reliability & 11,12 & 8.45 & 8.92 & 4.225 & 4.46 & 0.235 \\
\hline Responsiveness & 9,10 & 7.87 & 7.75 & 3.935 & 3.87 & -0.065 \\
\hline Assurance & $3,4,5$ & 12.57 & 12.07 & 4.19 & 4.023 & -0.167 \\
\hline Empathy & $6,7,8$ & 11.80 & 11.60 & 3.93 & 3.863 & -0.067 \\
\hline Tangibles & 1,2 & 8.05 & 7.90 & 4.025 & 3.95 & -0.075 \\
\hline
\end{tabular}

Dari tabel 2 dapat diketahui dimensi yang memiliki gap terbesar sampai dengan yang terkecil. Semakin besar gap yang didapat dari perhitungan gap 5 maka semakin kurang baiknya kualitas pelayanan jasa tersebut. Dan sebaliknya, semakin kecil gap yang didapat dari perhitungan gap 5 (gap tersebut nol dan positif) maka semakin baik kualitas pelayanan jasanya. Oleh karena itu, prioritas perbaikan pelayanan jasa dilakukan dari gap atau kesenjangan terbesar. Berdasarkan tabel 2 dapat dilihat bahwa dimensi kualitas jasa Reliability (Keandalan) pada restoran Mc Donald's memiliki gap yang bernilai positif. Dimensi kualitas jasa Reliability memiliki nilai gap 0.235.Dimensi Reliability ini perlu di pertahankan oleh restoran Mc Donald's karena telah berhasil memenuhi kepuasan pelanggan. Sedangkan dimensi kualitas jasa Responsiveness (daya tangkap), Assurance (jaminan), Tangibles (bukti fisik) dan Empathy (empati) Pada restoran Mc Donad's memiliki nilai gap yang negatif. Hal ini berarti keempat dimensi kualitas jasa ini belum berhasil memenuhi kepuasan pelanggan dan perlu adanya perbaikan.

Tabel 3 Urutan nilai Gap 5 dari Gap Terkecil Sampai Gap Terbesar Isi Tabel disesuaikan dengan hasil

\begin{tabular}{ccc}
\multicolumn{3}{c}{ studi, diurutkan dari yang terbesar hingga terkecil sesuai dengan Tabel 1 } \\
\hline Atribut & Pernyataan & Nilai Gap 5 \\
\hline 11 & Produk mudah dicari & 0.25 \\
\hline 12 & Lokasi mudah dijangkau & 0.22 \\
\hline 2 & Produk tersusun rapi & 0 \\
\hline 9 & Karyawan melayani dengan baik & 0 \\
\hline 3 & Produk lengkap & -0.05 \\
\hline 6 & Karyawan bersikap ramah & -0.05 \\
\hline 8 & Karyawan menyambut kedatangan pelanggan & -0.05 \\
\hline 7 & Karyawan murah senyum & -0.1 \\
\hline 5 & Kualitas produk sesuai harga & -0.3 \\
\hline 10 & Saran dan keluhan ditanggapi dengan baik & -0.13 \\
\hline 1 & Tempat nyaman dan bersih & -0.15 \\
\hline 4 & Produk yang ditawarkan berkualitas & -0.15 \\
\hline
\end{tabular}

Berdasarkan tabel 3, terdapat 4 atribut pernyataan yang bernilai gap positif (sudah memenuhi harapan konsumen) dan 8 atribut pernyataan yang bernilai gap negatif (perlu adanya evaluasi dan perbaikan). Atribut pernyataan yang bernilai positif adalah atribut nomor 11, 12, 2, dan 9. Sedangkan atribut pernyataan nomor $3,6,8,7,5,10,1$, dan 4 bernilai negatif. 


\section{Kesimpulan}

\section{KESIMPULAN DAN SARAN}

1. Atribut pernyataan yang bernilai negatif (perlu adanya evaluasi dan perbaikan) diantaranya adalah atribut nomor 3 yaitu "Produk lengkap" yang bernilai -0.05, atribut nomor 6 yaitu "Karyawan bersikap ramah" yang bernilai -0.05 , atribut nomor 8 yaitu "Karyawan menyambut kedatangan pelanggan" yang bernilai -0.05 , atribut nomor 7 yaitu "Karyawan murah senyum" yang bernilai 0.1 , atribut nomor 5 yaitu "Kualitas produk sesuai harga" yang bernilai -0.3, atribut nomor 10 yaitu "Saran dan keluhan ditanggapi dengan baik" yang bernilai -0.13, atribut nomor 1 yaitu "Tempat nyaman dan bersih" yang bernilai -0.15 dan atribut nomor 4 "Produk yang ditawarkan berkualitas" yang bernilai -0.15 .

2. Atribut pernyataan yang bernilai positif (sudah memenuhi harapan pelanggan dan perlu dipertahankan) diantaranya adalah atribut nomor 11 yaitu "Produk mudaah dicari" yang bernilai 0.25 , atribut nomor 12 yaitu "Lokasi mudah dijangkau" yang bernilai 0.22 , atribut nomor 2 yaitu "Produk tersusun rapih" yang bernilai 0 dan atribut pernyataan nomor 9 yaitu "Karyawan melayani dengan baik" yang bernilai 0 .

3. Dimensi jasa yang sudah memenuhi harapan pelanggan adalah dimensi jasa Reliability dengan nilai gap 0.235 .

4. Dimensi jasa yang belum memenuhi harapan pelanggan (perlu adanya evaluasi dan perbaikan) adalah dimensi jasa Responsiveness dengan nilai gap -0.065, dimensi jasa assurance dengan nilai gap -0.167, empathy dengan nilai gap -0.067, dan dimensi jasa Tangibles dengan nilai gap -0.075

\section{DAFTAR PUSTAKA}

1. Hendy Tannady. Metode DMAIC sebagai solusi pengendalian kualitas produksi sepatu tambang : studi kasus pt mangul jaya-bekasi. Jurnal Comtech-Computer, Mathematics and Engineering Applications, 3(1):509-523, 2012.

2. Hendy Tannady. Mengoptimalkan lalu-lintas perbelanjaan dengan mengatur derajat kepentingan antar etalase. Jurnal Comtech-Computer, Mathematics and Engineering Applications, 3(1):503-508, 2012.

3. Hendy Tannady, Steven. Efisiensi waktu produksi es batu sebagai implikasi urutan penjadwalan kedatangan job yang tepat. Jurnal Ilmiah Teknik Industri (JITI), 11(1):91-101, 2012.

4. Jevi Rosta, Hendy Tannady. Pendistribusian produk yang optimal dengan metode transportasi. Jurnal Teknik dan Ilmu Komputer (JTIK), 01(4):347-352, 2012.

5. Hendy Tannady, Andrew V. Limas. Simulasi penjadwalan travelling salesman problem di Sembilan kota dengan algoritma genetika. Jurnal Comtech-Computer, Mathematics and Engineering Applications, 3(2):977-982, 2012.

6. Jevi Rosta, Hendy Tannady. Perencanaan Agregat Heuristik Untuk Penentuan Sumber Daya Yang Optimal. Jurnal Spektrum Industri, 11(1):91-97, 2013.

7. Hendy Tannady. Simulasi Antrian : Suatu Tinjauan Konsep Pustaka. Journal of Industrial Engineering and Management System (JIEMS), 6(1):23-32, 2013.

8. Jevi Rosta, Hendy Tannady. Aplikasi AHP Dalam Menentukan Kandidat Gubernur DKI Jakarta 2012-2017. Jurnal Comtech-Computer, Mathematics and Engineering Applications, 4(1):394-406, 2013. 
9. Hendy Tannady. Modifikasi Mekanisme Penentuan Penjadwalan Job Pada Metode Dannenbring. Jurnal Ilmiah Teknik Industri, 12(1):01-09, 2013.

10. Hendy Tannady, Fan Andrew. Analisis Perbandingan Metode Regresi Linier dan Exponential Smoothing Dalam Parameter Tingkat Error. Jurnal Teknik dan Ilmu Komputer (JTIK), 02(07):242-250, 2013.

11. Hendy Tannady. Pengaturan Ulang Urutan Tata Letak Seri Antar Etalase. Journal of Industrial Engineering and Management System (JIEMS), 6(2):01-07, 2013.

12. Hendy Tannady. Perancangan Pemenuhan Permintaan Pasokan Gula Rafinasi Dengan Metode Wagner Whitin. Jurnal Teknik Industri (JATI), 8(3):187-192, 2013.

13. Hendy Tannady. Pemetaan Kompetisi Perguruan Tinggi Dengan Brand Measurement. Jurnal Manajemen, 9(2):15-27, 2013.

14. Andrew V. Limas, Adrians P, Nandhika W, Hendy Tannady. Pembahasan Mengenai Efek Urban Heat Island Dan Solusi Alternatif Bagi Kota Jakarta. Jurnal Teknik Industri (JATI), 9(1):29-34, 2014.

15. Hendy Tannady, Riyan, Wahyu Eka. Modifikasi Waktu Standard Pelayanan Untuk Meminimumkan Jumlah Antrian. Jurnal Teknik dan Ilmu Komputer (JTIK), 3(9):41-47,2014.

16. Hendy Tannady. Optimasi Produksi Meubel Menggunakan Model Pemrograman Linier. Jurnal Manajemen, 10(1):01-09, 2014.

17. Hendy Tannady, Erwin Adianto. Analisa Studi Gerakan Dan Simulasi Antrian Untuk Peningkatan Produktivitas Pada Pelayanan Servis Motor. Jurnal Ilmiah Teknik Industri (JITI), 2(2):109-114, 2014.

18. Hendy Tannady. Aplikasi Simulasi Monte Carlo Tidak Terstruktur Pada Scheduling Karyawan Maintenance Engineering. Jurnal Teknik dan Ilmu Komputer (JTIK), 3(11):229-235, 2014.

19. Hendy Tannady. Penentuan Biaya Optimum Pada Permasalahan Transportasi Seimbang Dengan VAM dan MODI. Journal of Industrial Engineering and Management System (JIEMS), 7(2):140-147, 2014.

20. Hendy Tannady, Riky Mulyadi, Ricky Cahyadi. Penentuan Jenis Investasi Dengan Analisa Ekonomi Teknik Dan Forecasting. Jurnal Ilmiah Teknik Industri, 13(02):134-140, 2014.

21. Hendy Tannady, Steven, Andrew V. Limas. Solusi Urutan Pengerjaan Job Yang Tepat Dengan Metode Campbell Dudek Smith (CDS) (Studi Kasus : Pabrik Es PT. $x y z$, Kabupaten Luwuk, Sulawesi Tengah). Jurnal Teknik Industri (JATI), 10(01):51-54, 2015.

22. Hendy Tannady, Wahyu Eka Munardi. Pengamatan Waktu Pelayanan Operator Pintu Tol Dengan Uji Hipotesis ANOVA (Studi Kasus : Gerbang Tol Ancol Timur, Jakarta Utara).Journal of Industrial Engineering and Management System (JIEMS), 8(01):26-54, 2015. 
23. Hendy Tannady, Riky Mulyadi. Model Kano Dalam Mengukur Kepuasan Pelanggan Di Restauran Cepat Saji. Jurnal Spektrum Industri, 13(01):85-90, 2015.

24. Chaniago Helmi Santoso, Hendy Tannady, Dino Caesaron. Analisis Kemacetan Di Jalan Tol Lingkar Dalam Kota Jakarta (Gerbang Tol Cililitan). Jurnal Teknik dan Ilmu Komputer (JTIK), 04(14):163-174, 2015.

25. Hendy Tannady, Chaniago Helmi Santoso, Michael Kelly, Tandianto. Mengukur Produktivitas Kerja Karyawan Seven Eleven Mangga Dua. Journal of Industrial Engineering and Management System (JIEMS), 8(02):1-6, 2015.

26. Michael Kelly Sawlani, Hendy Tannady. Perencanaan dan Pengendalian Bahan Baku Polyester Fleece Fabrics Dengan Pola Data Statik (Studi Kasus : PT. Asia Pacific Fibers, Tbk-Karawang). Jurnal Pasti, 09(01):63-73, 2015.

27. Yona Maimury, Hendy Tannady. Analisis Kinerja Proses Latex Dipping Menggunakan Teknik Capability Process (Studi Kasus : PT. Dharma Medipro). Jurnal Ilmiah Teknik Industri, 14(2):105-112, 2015.

28. Hendy Tannady. Studi Analisa Kompetisi Produk Teh Hijau Dalam Kemasan. Jurnal Teknik dan Ilmu Komputer (JTIK), 05(17):43-50, 2016.

29. Clara Valentina Gunawan, Hendy Tannady. Analisis Kinerja Proses dan Identifikasi Cacat Dominan Pada Pembuatan Bag Dengan Metode Statistical Process Control. Jurnal Teknik Industri (JATI), 11(1):09-14, 2016.

30. Andrey Thio, Hendy Tannady. Analisa Pekerjaan Konstruksi dan Penentuan Jalur Kritis Dengan Critical Path Method(Studi Kasus Pekerjaan Renovasi Pada Kantor Harvest Kemang). Jurnal Teknik dan Ilmu Komputer (JTIK), 05(16):01-10, 2016.

31. Seri Hendra, Hendy Tannady. Implementasi Metode Work Sampling Guna Mengukur Produktivitas Penjaga Kasir Di McDonald's Harapan Indah, Bekasi Barat. Journal of Industrial Engineering and Management System (JIEMS), 09(01):65-76, 2016.

32. Jessie Makapedua, Hendy Tannady. Analisis Pengukuran Kerja Operator dan Usulan Perbaikan Dengan Work Sampling (Studi Kasus : McDonald Hayam Wuruk). Jurnal Teknik dan Ilmu Komputer (JTIK), 05(19):295-304, 2016.

33. Hendy Tannady, Calvin Chandra. Analisis Pengendalian Kualitas dan Usulan Perbaikan Pada Proses Edging di PT Rackindo Setara Perkasa Dengan Metode Six Sigma. Journal of Industrial Engineering and Management System (JIEMS), 09(02):123-139, 2016.

34. Hendy Tannady, Gunawan. Implementasi Six Sigma pada Perbaikan Kualitas Proses Produksi Frame Chassis Pada Assembly Line B (Studi Kasus PT Gemala Kempa Daya). Jurnal Teknik dan Ilmu Komputer (JTIK), 06(22):143-162, 2017.

35. Christian Lois, Janny Rowena, Hendy Tannady. Perencanaan dan Pengendalian Persediaan Bahan Baku Benang Dengan Lot Sizing Economic Order Quantity (Studi Kasus:CV. Prima Sejati, Tangerang, Banten). Journal of Industrial Engineering and Management System (JIEMS), 10(02):111-118, 2017. 
36. Helena Sisilia Ratna Soetopo, Hendy Tannady. Process Capability Analysis Pada Nut (Studi Kasus:PT. Sankei Dharma Indonesia). Jurnal Teknik Industri (JATI), 12(02):137-142, 2017.

37. Hendy Tannady, Kenrick Filbert. Pengendalian Persediaan Dengan Menggunakan Metode Economic Order Quantity Dan Silver Meal Algorithm (Studi Kasus:PT. SAI). Jurnal Teknik dan Ilmu Komputer (JTIK), 07(25):37-43, 2018.

38. Hendy Tannady. Mengkaji Kepuasan Pelanggan Terhadap Kualitas Layanan ECommerce Dengan Menggunakan Metode Importance Performance Analysis 3 Dimensi. Journal of Business \& Applied Management, 11(01):116-135, 2018.

39. Yuliana, Hendy Tannady. Faktor Determinan Performa Pekerja Konstruksi Melalui Media Motivasi. Journal of Business and Applied Management, 12(2):169$185,2019$.

40. Hendy Tannady, Yohanes Dwi Pratama. Analisis Perencanaan Persediaan Bahan Baku Menggunakan Metode Economic Order Quantity Dengan Pertimbangan Stockout Cost (Studi Kasus PT. Multi Logam Presisi). Jurnal Spektrum Industri, 17(2):93-97, 2019.

41. Hendy Tannady, Dwi Yanasari, Salma Nur Kamila, Vinna Adhe Fitria, Ramdhan Sofyan. Upaya Meningkatkan Kualitas Pelayanan Di Outlet Hennes \& Mauritz Widforss Menggunakan Analisis Service Quality. Journal of Business and Applied Management, 13(1):19-32, 2020.

42. Hendy Tannady, Yohanes Totok Suyoto, Fuji Rahayu Wilujeng. Usulan Perbaikan Tata Letak Mesin Pada Pabrik Segel Plastik (Studi Kasus PT. Sinwa Perdana Mandiri). Journal of Industrial and Manufacture Engineering, 4(1):22-27, 2020.

43. Hendy Tannady. Analisis Perbaikan Terhadap Antrian Pada Pom Bensin Rawalumbu. Jurnal Ilmiah Teknik Industri, 8(2):148-152, 2020. 